\section{Geology of Cephaionia}

In answer to the inquiry of your correspondent in the last nuraber of NATURE (P. 173) I leg to inform him that the shells of the Pliocene formation in the Morea have been long since investigated, as is shown by the great and well-known work of Hömes. And Dr. Fischer has published a list of the fossil stells from the same formation at Khodes. T'hese subapennine beds extend over the whole of the suth of Europe. For many of those species which are still living I have given the localities of the Morea and Rhodes as fossil in the Procedings of the Zoological Socitty.

J. GWYN JEFFREYS

June 25

On the Chemical Characters of the Venom of Serpents

$D_{R}$, WEIR MrTcheLL calls my attention to an error in the brief notice which I wrote in NATURE recently (vol. xxriii. p. II 4 ), on the researches into the elemical characters of snaks poison conducted by him ard Dr. Reichart. It is that instear of "They are unable to confirm the statement of Gautier of Paris that an alkaloid resembling a ptomaine exists in cobra poison; or that of Prof. Wolcott Gebts, that the poison of Crotalus yield's an alkaloid," it should be, "Prof. Wolcott Gibbs was mrable to find an alkaloid."

53, Wimpole Street, W., Junc 26

J. FAYRER

\section{Earthquake in South-West England}

I HAve just felt and heard the sbock of an earthquake. The tremiling of the 1 arth $n$ as very great and the accompanying noise very lout, comparing it with one or two other slight shocks which I have before experienced in this district, I found the time to be $1.3^{8}$ p.r. The time it lasted was several seconds. It was longer and louc'er than an ordinary clap of thunder when the lightning is not far off. A man reports that the slates of the cow-house were made to rattle.

As I now write $(2.7 \mathrm{p}, \mathrm{m}$.$) a second shock has been felt, a little$ less severe. The weather is very calm, sky cloudy. 'I'his place is close to Dartmoor, on the westward side, about 500 feet above the sea-Ievel.

Wocdtown, Horrabridge, S. Levon, June 25 W. F. COLLIRR

I BEG to inform you of the occurence of two slight earthquake shocks here to-day, one shortly befure $2 \mathrm{pm}$., the ther near half an hour later. The direction of progress seemed to be from north.west to south-east-that is along the line of the deep and natrot valley. The tremor was sufficient to cause jangling of ghass and earthenware, and of the slates covering the house. The usual rumbling noise accompanicd the shocks.

Petralla Terrace, Bo: cattle, Corrtwall, June 25 SAMUEL DREW

ON WHALES, PAST AND PRESENT, AND THEIR PROBABLE ORIGIN

$\mathrm{F} E W$ natural groups present so many remarkable, very obvious, and essily appreciated illustrations of several of the most important general laws which appear to have determined the structure of animal bodies, as those selected for my lecture this evening. We shall find the effects of the two opposing forces-that of heredity or conformation to ancestrat characters, and that of adaptation to changed environment, whether brought about by the method of natural selection or otherwise-distinctly written in almost every part of their structure. Scarccly anywhere in the animal kingdom do we see so many cases of the persistence of rudimentary and apparently useless organs, those marvellous and suggestive phcnomena which at one time seemed hopcless enigmas, causing despair to those wLu tried to unravel their meaning, looked upon as mere will- of the-rifisps, but now eagerly welcomed as beacons of true light, casting illuminating beams upon the dark and otherwise impenetrable paths through which the organism has travelled on its way to reach the goal of its present condition of existence.

Lecture delivered at the Royal Institution on the evening of Friday, May 25, $188_{3}$, by Prof. Flower, LL.D., F.R.S., P.Z.S, \&c.
It is chiefly to these rudimentary organs of the Cetacea and to what we may learn from them that I propose to call your attention. In each case the question may well be asked, granted that they are, as they appear to be, useless, or nearly so, to their present possessors, insignificant, imperfect, in fact rudimentary, as compared with the corresponding or homologous parts of other animals, are they suryivals, remnants of a past condition, become useless owing to change of circumstances and environment, and undergoing the process of gradual degeneration, preparatory to their final removal from an organism to which they are only, in however small a degree, an incumbrance, or are they incipient structures, beginnings of what may in future become functional and important parts of the economy? These questions will call for an attempt at least at solution ir each case as we proceed.

Before entering upon details, it will be necessary to give sume general idea of the position, limits, and principal modifications of the group of animals from which the special illustrations will be drawn. The term "whale", is commonly but vaguely applied to all the larger and middle-sized Cetacea, and though such smaller species as the dolphins and porpoises are not usually spoken of as whales, they may to all intents and purposes of zoological science be included in the term, and will come within the range of the present subject. Taken all together the Cetacea constitute a perfectly distinct and natural order of mammals, characterised by their purely aquatic mode of life and external fishlike form. The body is fusiform, passing anteriorly into the head without any distinct constriction or neck, and posteriorly tapering off gradually towards the extremily of the tail, which is provided with a pair of lateral pointed expansions of skin supportcd by dense fibrous tissue, called "flukes," forming logether a horizontally-placcd, triangular propelling organ. The forelimbs are reduced to the condition of flattened ovoid paddles, incascd in a continuous integument, showing no external sign of division into arm, forearm, and hand, or of separate digits, and without any trace of nails. There are no vestiges of hind-limbs visible externally. The general surface of the body is smooth and glistening, and devoid of hair. In nearly all species a compressed median dorsal fin is present. The nostrils oper sep:rately or by a single crescentic valvular aperture, not at the extrenity of the snout, but near the vertex.

Anitrals of the order Cetacea abound in all known seas, and some species are inhabitants of the larger rivers of South America and Asia. Their organisation necessitates their life being passed entirely in the water, as on the land they are absolutely helpless; but they have to rise very frequently to the surface for the pirpose of respiration. They are all predaceous, subsisting on Iiving animal food of some kind. One genus alone (Orca) eats other warm-blooded animals, as seals and even members of its own order, both large and small. Some feed on fisb, others on smali foating crustacea, pteropods, and medusa, while the staple food of many is constituted of the various species of Cephalopods, chiefly Loligo and other Teuthida, which must abound in some seas in vast numbers, as they form almost the entire support of some of the larsrest members of the order. With some excejtions the Cetacea generally are timid, inoffensive animals, active in their movements, sociable ancl gregarious in their babits.

Among the existing members of the order there are two very distinct types-the Toothed Whales, or Odontoceti, and the Baleen Whales, or Mystacoceti, which present throughout their organisation most markedly distinct structural characters, and have in the existing state of nature no transitional forms. The extinct Zeuglodon, so far as its characters are known, does not fall into either of these groups as now constituted, but is in some respects intermediate, and in others more resembles the generalised mammalian type, 